\title{
Impact of weather on the spring crops yield in Croatia with emphasis on climatic change and the 2014 growing season
}

\author{
V. Kovacevic - J. Sostaric \\ University J. J. Strossmayer in Osijek, \\ Faculty of Agriculture, Osijek, Croatia
}

\begin{abstract}
SUMMARY
Main field crops in Croatia are maize, soybean, sunflower and sugar beet. By these crops are covered (status 2014) close to 50\% (385 234 ha) of utilized arable land. Global warming, have often adverse influence on field crop yields. Aim of this study was testing precipitation and temperature regimes on spring crops yield in Croatia in 15-year period (1999-2013) and elaboration of the 2014 growing season with aspect of climatic change.

Four growing seasons (2000, 2003, 2007 and 2012) were less favorable for maize because annual yield was bellow 5 tha ${ }^{-1}$ (average $4.38 \mathrm{t} \mathrm{ha}^{-1}$ ), while in four more favorable years $\left(2005,2008,2009\right.$ and 2010) annual yield was above $6.8 \mathrm{tha^{-1 }}$ (average $7.32 \mathrm{tha^{-1 }}$ ). Average precipitation and temperature for the April-September period in Osijek were $226 \mathrm{~mm}$ and $496 \mathrm{~mm}, 19.6^{\circ} \mathrm{C}$ and $18.6^{\circ} \mathrm{C}$, for less and more favorable years, respectively. Yields of soybeans and sugar beet have mainly similar trend as maize yields in function of weather conditions, while sunflower is more susceptible to extremely moist growing seasons (for example, 2001 and 2005: $650 \mathrm{~mm}$ and $697 \mathrm{~mm}$ precipitation

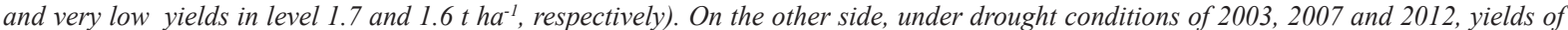

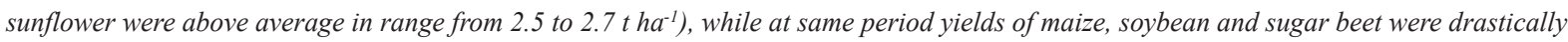
reduced.

Average precipitation in the April-September period of 2014 for eight selected sites of Croatia was 756 mm or for $68 \%$ higher in comparison with the long-term average 1961-1990 with variation among the sites from $520 \mathrm{~mm}$ in Osijek to $910 \mathrm{~mm}$ in Varazdin. On the other side, average air-temperature in 2014 was $17.8^{\circ} \mathrm{C}$ or for $0.7^{\circ} \mathrm{C}$ higher with variations among the sites from $17.2^{\circ} \mathrm{C}$ in Daruvar and Varazdin to $18.2^{\circ} \mathrm{C}$ in Osijek and $18.3^{\circ} \mathrm{C}$ in Gradiste. Under these favorable weather conditions, annual yields of maize (8.1 tha $\left.{ }^{-1}\right)$, soybeans $\left(2.8 \mathrm{tha} \mathrm{a}^{-1}\right)$, sunflower $\left(2.9 \mathrm{th}^{-1}\right)$ and sugar beet $\left.63.6 \mathrm{th \textrm {h } ^ { - 1 }}\right)$ were considerable higher than usual.
\end{abstract}

Keywords: maize, sunflower, soybeans, sugar beet, climatic change, precipitation, temperature, Croatia

\section{INTRODUCTION}

Main field crops in Croatia are maize, soybean, sunflower and sugar beet. By these crops were covered (status 2014) 252567 ha (maize for grain), 28794 ha (silage maize), 47104 ha (soybeans), 34869 ha (sunflower) and 21900 ha (sugar beet) or 47.5\% (385 234 ha) of utilized arable land (CBS, 2015).

Global warming and more frequency of the extremely weather conditions, mainly long drought periods and floods, is associated with climatic change. With that regards, recent status of precipitation and temperature regimes, have often adverse influence on field crop yields as well the higher amplitude their variations among years. For this reason, in many countries there is a tendency towards cereal grain yield stagnation and increased yield variability (Tim, 2000; Chi-Chung et al., 2004; Parrx et al., 2004; Vucetic, 2006, 2011; Lobel and Field, 2007; Li et al., 2011; Oseni and Masarirambi, 2011; Kovacevic et al., 2012, 2014; Liovic et al., 2012; Komljenovic et al., 2014). Some studies have indicated that $1{ }^{\circ} \mathrm{C}$ increase in global temperature will lead to reduced productivity in some cultivated plants, such as $17 \%$ in maize and soybean (Allen et al., 2003; Thomson et al., 2005). In the recent period, very high yield reduction of maize due to drought and high air-temperatures were found for the continental climate in the Pannonia zone, which includes Hungary, Croatia, Serbia, Bulgaria and Romania (Kovacevic et al., 2012, 2013).

Aim of this study was testing precipitation and temperature regimes on spring crops yield in Croatia in recent 15-year period (1999-2013) and elaboration of the 2014 growing season with aspect of climatic change.

\section{MATERIAL AND METHODS}

\section{Description of the area}

According to geographical characteristics, there are three regions in Croatia: the Mediterranean or the Adriatic region, the Mountainous region and the Pannonia region. The Pannonian region covers about $50 \%$ of Croatian territory and majority arable land and the harvested area of main field crops of the country is situated in this part of Croatia. More details about geographical position, relief, soil, climate and water resources, as well as phytogeographical characteristics, were shown in the correspondingly monography (Magas, 2013), while Kovacevic and Basic (1997) reported data with emphasis on the agroecological aspect.

The meteorological stations of eight sites situated in Pannonia region of Croatia (Figure 1) were selected for characterization of weather conditions with aspect of their degree of favorability for the spring crops growth in the 2014 growing season. This region is mainly lowland area and selected sites are elevated between 81 to $163 \mathrm{~m}$ above sea level (Figure 1).

\section{Collection of data}

Publications of Croatian Bureau of Statistics were used as the sources of the utilized agricultural and arable land areas, the spring crops (maize, soybeans, sunflower and sugar beet) harvested areas and yields (CBS, 2009, 2014, 2015), while publications of Meteorological and Hydrological Service Zagreb were 
perused for the meteorological data (monthly values of precipitation and average air-temperatures (MHS, 1999-2013, 2014).

\section{RESULTS AND DISCUSSION}

By utilized agricultural area in Croatia were covered 1270044 ha (average 2004-2013) and 1508885 ha (status 2014) and utilized arable land participated with $68.6 \%$ and $53.7 \%$ of utilized agricultural area, respectively. Main spring crops on arable land in Croatia are maize for grain, soybean, sunflower and sugar beet (averages in 2004-2013 period: 301046 ha, 49121 ha, 33081 ha and 25644 ha, respectively). In general, considerable yield variations of the mentioned crops among years were found. With that regards, the 2014 growing season characterized by yields above 10 -year averages (Table 1). As soil properties, crop management practices and used cultivars in this short period were similar, yield differences among years could be attributed mainly to specify of weather characteristics in individual growing season.

Figure 1: Position of selected meteorological stations (MS), their geographical coordinates and elevation above sea level

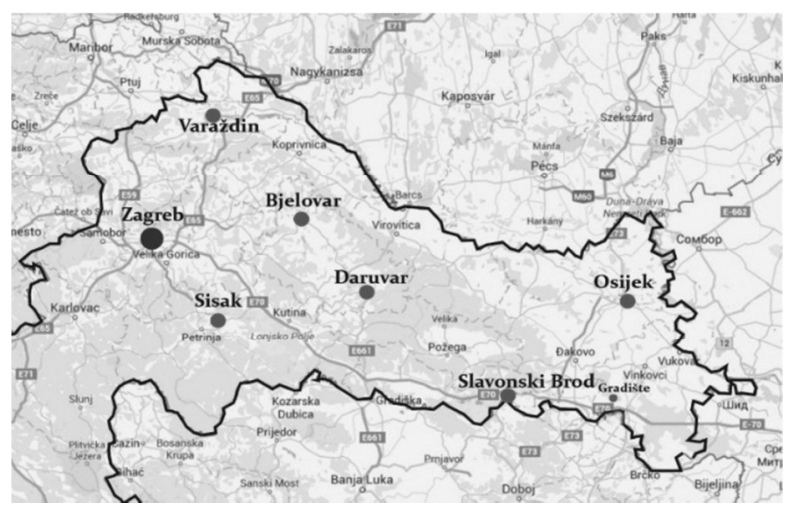

MS

Coordinates and elevation

Osijek (OS)

Gradiste (GR)

Slav. Brod (SB)

Daruvar (DA)

Bjelovar (BJ)

Sisak (SI)

Zagreb (ZG)

Varazdin (VZ) $45^{\circ} 33^{\prime} 44^{\prime \prime} \mathrm{N} 18^{\circ} 42^{\prime} 00^{\prime \prime} \mathrm{E} ; 102 \mathrm{~m}$ $45^{\circ} 04^{\prime} 20^{\prime \prime N} 18^{\circ} 41^{\prime} 40^{\prime \prime} \mathrm{E} ; 81 \mathrm{~m}$ $45^{\circ} 09^{\prime} 36^{\prime \prime N} 18^{\circ} 00^{\prime} 36^{\prime \prime} \mathrm{E} ; \quad 90 \mathrm{~m}$ $45^{\circ} 35^{\prime} 34^{\prime \prime N} 17^{\circ} 13 ' 25^{\prime \prime} \mathrm{E} ; 163 \mathrm{~m}$ $45^{\circ} 54^{\prime} 36^{\prime \prime N} 16^{\circ} 50^{\prime} 24 " \mathrm{E} ; 111 \mathrm{~m}$ $45^{\circ} 28^{\prime} 48^{\prime \prime} \mathrm{N} 16^{\circ} 21^{\prime} 36 " \mathrm{E} ; 102 \mathrm{~m}$ $45^{\circ} 48^{\prime} 43^{\prime \prime N} 15^{\circ} 58^{\prime} 52^{\prime \prime} \mathrm{E} ; 125 \mathrm{~m}$ $46^{\circ} 18^{\prime} 15^{\prime \prime} \mathrm{N} \mathrm{16}{ }^{\circ} 20^{\prime} 16^{\prime \prime E} ; 154 \mathrm{~m}$

From OS to VZ: air-distance approximately $200 \mathrm{~km}$

Table 1.

The harvested areas and yields of main spring field crops in Croatia

\begin{tabular}{|c|c|c|c|c|c|c|c|c|c|c|c|}
\hline \multicolumn{2}{|c|}{$\begin{array}{l}\text { The utilized area } \\
\text { (ha) }\end{array}$} & \multicolumn{5}{|c|}{$\begin{array}{l}\text { The harvested area } \\
\text { (ha) }\end{array}$} & \multicolumn{5}{|c|}{$\begin{array}{l}\text { Yield } \\
\left(\mathrm{t} \mathrm{ha}^{-1}\right)\end{array}$} \\
\hline \multirow{2}{*}{$\begin{array}{l}\text { Agric. } \\
\text { area }\end{array}$} & \multirow{2}{*}{$\begin{array}{c}\text { Arable } \\
\text { land }\end{array}$} & \multicolumn{2}{|c|}{ Maize } & \multirow{2}{*}{$\begin{array}{l}\text { Soy- } \\
\text { bean }\end{array}$} & \multirow{2}{*}{$\begin{array}{l}\text { Sun- } \\
\text { flower }\end{array}$} & \multirow{2}{*}{$\begin{array}{c}\text { Sugar- } \\
\text { beet }\end{array}$} & \multicolumn{2}{|c|}{ Maize } & \multirow{2}{*}{$\begin{array}{l}\text { Soy- } \\
\text { bean }\end{array}$} & \multirow{2}{*}{$\begin{array}{l}\text { Sun- } \\
\text { flower }\end{array}$} & \multirow{2}{*}{$\begin{array}{c}\text { Sugar- } \\
\text { beet }\end{array}$} \\
\hline & & Grain & Silage & & & & Grain & Silage & & & \\
\hline \multicolumn{12}{|c|}{ Republic of Croatia - 10-year averages (2004-2013) } \\
\hline \multirow[t]{3}{*}{1270044} & 871321 & 301046 & 26547 & 49121 & 33081 & 25644 & 6.35 & 31.6 & 2.45 & 2.60 & 49.6 \\
\hline & & Annual yi & variatic & in 2004 & 013 perio & Minimum & 4.40 & 25.8 & 1.80 & 1.60 & 39.1 \\
\hline & & & & & & Maximum & 8.00 & 37.5 & 3.00 & 3.20 & 57.7 \\
\hline \multicolumn{12}{|c|}{ Republic of Croatia - the 2014 growing season } \\
\hline 1508885 & 811067 & 252567 & 28794 & 47104 & 34869 & 21900 & 8.10 & 35.3 & 2.80 & 2.90 & 63.60 \\
\hline
\end{tabular}

Source: CBS (2009, 2014, 2015)

Variation of maize yields in Croatia during 15-year period 1999-2013 could be used as typical example of impact precipitation and temperature regimes on maize yields. Annual yield variation in this period was from $4.1 \mathrm{t} \mathrm{ha}^{-1}$ in 2000 to $8.0 \mathrm{t} \mathrm{ha}^{-1}$ in 2008 . Four growing seasons were less favorable for maize (2000, 2003, 2007 and 2012) because annual yield was below $5 \mathrm{t} \mathrm{ha}^{-1}$ (average $4.38 \mathrm{tha}^{-1}$ ), while in four more favorable years $(2005,2008,2009$ and 2010) annual yield was above $6.8 \mathrm{t} \mathrm{ha}^{-1}$ (average $7.32 \mathrm{t} \mathrm{ha}^{-1}$ ). Average precipitation and temperature for the April-September period in Osijek were $226 \mathrm{~mm}$ and $496 \mathrm{~mm}, 19.6^{\circ} \mathrm{C}$ and $18.6^{\circ} \mathrm{C}$, for less and more favorable years, respectively (Table 2).

Low yields of maize in unfavorable years were in close connection with drought in June and August (total $15 \mathrm{~mm}$ precipitation) and high air-temperature $\left(23.7^{\circ} \mathrm{C}\right)$ in August of 2000 , high temperatures in June $\left(24.3{ }^{\circ} \mathrm{C}\right)$ and August $\left(23.6^{\circ} \mathrm{C}\right)$ accompanied with moderate precipitation in 2003 , drought and high temperature in June and July of 2007 (58 mm precipitation and temperature $23.1^{\circ} \mathrm{C}$ ) in 2007 , while extremely drought and high temperature in August (4 mm and $24.8^{\circ} \mathrm{C}$ ) were responsible for low yield of maize in 2012 (Table 2). Specifies of unfavorable the 2012 growing season (Meteorological Station Osijek) were the highest average air-temperature in level $20.0{ }^{\circ} \mathrm{C}$ for AprilSeptember period (Table 3 ) and absolute maximum in August $40.3{ }^{\circ} \mathrm{C}$ (Kovacevic et al., 2013). The highest annual yield of maize in Croatia for 1999-2013 periods were recorded in 2008. This growing season was characterized by adequate $(404 \mathrm{~mm})$ and good distributed monthly precipitation, as well as the lower temperature (average $18.1^{\circ} \mathrm{C}$ ) without considerable oscillations (21.5 ${ }^{\circ} \mathrm{C}$ in June, $21.8^{\circ} \mathrm{C}$ in July and $21.8^{\circ} \mathrm{C}$ in August).

Kovacevic et al. (1994) reported survey of maize yield and precipitation regime for 1960-1990 period in Slavonia and Barannya which approximately covers the eastern Croatia region. In this study was found similar impact of weather conditions on maize yield as in our study. In this period, the average harvested area of maize in Croatia 509068 ha and it was relative stabile among the years, while yields had the increasing trend 
as follows: $2.90 \mathrm{tha}^{-1}, 3.85 \mathrm{tha}^{-1}$ and $4.68 \mathrm{tha}^{-1}$, for decade periods 1960 -ies, 1970 -ies and 1980 -ies, respectively.

Yields of soybeans and sugar beet have mainly similar trend as maize yields in function of weather conditions impacts, while sunflower is more susceptible to extremely moist growing seasons (for example, 2001 and 2005: $650 \mathrm{~mm}$ and $697 \mathrm{~mm}$ precipitation and very low yields in level 1.7 and 1.6 t ha $^{-1}$, respectively) compared to remaining three analyzed spring crops. On the other side, under drought conditions of 2003, 2007 and 2012, yields of sunflower were in range from 2.5 to $2.7 \mathrm{tha}^{-1}$ ), while yields of maize, soybean and sugar beet were drastically reduced (Table 2).

Average precipitation in the April-September period of 2014 for eight selected sites of Croatia was $756 \mathrm{~mm}$ or for $68 \%$ higher in comparison with the long-term average (LTA) 1961-1990 with variation among the sites from $520 \mathrm{~mm}$ in the eastern situated Osijek to $910 \mathrm{~mm}$ in western situated Varazdin. On the other side, average air-temperature in 2014 was $17.8^{\circ} \mathrm{C}$ or for $0.7^{\circ} \mathrm{C}$ higher with variations among the sites from $17.2^{\circ} \mathrm{C}$ in Daruvar and Varazdin to $18.2^{\circ} \mathrm{C}$ in Osijek and $18.3^{\circ} \mathrm{C}$ in Gradiste (Table 3). In general, climate trend in the Pannonia region is characterized by increase of annual precipitation and decrease of temperature in direction from east toward west (Rastija et al., 2012; Magas, 2013; Kovacevic and Rastija, 2014). Our data are in accordance with these observations. Also, we confirmed of climate change by global warming (Lobel and Field, 2007; Vucetic, 2011).

The 2014 growing was very favorable for the majority spring crops because of adequate and good monthly distributed precipitation and avoidance of extremely high air-temperatures (Table 3).

Yields of main spring crops in Croatia and weather conditions in Osijek

Table 2 .

\begin{tabular}{|c|c|c|c|c|c|c|c|c|c|c|c|c|c|c|c|}
\hline & & & & & & & & Year & & & & & & & \\
\hline & 1999 & 2000 & 2001 & 2002 & 2003 & 2004 & 2005 & 2006 & 2007 & 2008 & 2009 & 2010 & 2011 & 2012 & 2013 \\
\hline & \multicolumn{15}{|c|}{ Yields of main spring crops in Croatia $\left(\mathrm{t} \mathrm{ha}^{-1}\right)$} \\
\hline Maize & 5.6 & 4.1 & 5.7 & 6.4 & 4.2 & 6.3 & 6.9 & 6.5 & 4.9 & 8.0 & 7.4 & 7.0 & 5.7 & 4.3 & 6.5 \\
\hline Soybean & 2.5 & 1.4 & 2.2 & 2.7 & 1.7 & 2.7 & 2.5 & 2.8 & 1.9 & 3.0 & 2.6 & 2.7 & 2.5 & 1.8 & 2.4 \\
\hline Sunflower & 2.1 & 2.1 & 1.7 & 2.3 & 2.5 & 2.4 & 1.6 & 2.3 & 2.6 & 3.1 & 3.0 & 2.3 & 2.8 & 2.7 & 3.2 \\
\hline \multirow[t]{2}{*}{ Sugarbeet } & 40.0 & 23.0 & 40.6 & 47.1 & 24.8 & 47.6 & 45.5 & 48.9 & 46.1 & 57.7 & 52.8 & 52.4 & 53.8 & 39.1 & 51.9 \\
\hline & \multicolumn{15}{|c|}{ Precipitation in Osijek (mm) } \\
\hline April-September & 505 & 155 & 650 & 461 & 227 & 471 & 697 & 417 & 229 & 404 & 206 & 677 & 246 & 293 & 425 \\
\hline June & 150 & 10 & 239 & 37 & 44 & 77 & 112 & 91 & 33 & 76 & 63 & 234 & 50 & 68 & 63 \\
\hline July & 96 & 63 & 77 & 59 & 60 & 44 & 171 & 15 & 27 & 79 & 14 & 32 & 74 & 48 & 37 \\
\hline \multirow[t]{2}{*}{ August } & 74 & 5 & 7 & 84 & 42 & 107 & 238 & 134 & 45 & 46 & 61 & 111 & 5 & 4 & 33 \\
\hline & \multicolumn{15}{|c|}{ Mean air-temperature in Osijek $\left({ }^{\circ} \mathrm{C}\right)$} \\
\hline April-September & 18.7 & 19.7 & 17.8 & 18.3 & 19.6 & 17.3 & 17.7 & 18.3 & 19.1 & 18.6 & 19.6 & 18.3 & 19.4 & 20.0 & 18.6 \\
\hline June & 20.3 & 22.5 & 18.1 & 21.1 & 24.3 & 19.2 & 19.5 & 20.1 & 22.3 & 21.5 & 19.2 & 20.4 & 20.8 & 22.5 & 20.0 \\
\hline July & 21.9 & 21.7 & 21.6 & 22.3 & 22.1 & 21.5 & 21.5 & 23.5 & 23.8 & 21.8 & 23.2 & 23.2 & 22.2 & 24.8 & 22.9 \\
\hline August & 21.3 & 23.7 & 22.7 & 20.9 & 23.6 & 21.0 & 19.3 & 19.3 & 22.2 & 21.8 & 22.9 & 21.7 & 23.1 & 24.1 & 22.9 \\
\hline
\end{tabular}

Source: CBS (2005, 2009, 2014), MHS (1999-2013)

Table 3 .

Weather conditions in eight selected sites of Pannonian region in Croatia (MHS, 2014)

\begin{tabular}{|c|c|c|c|c|c|c|c|c|c|c|c|c|c|c|c|c|c|c|}
\hline \multirow{5}{*}{ Month } & \multicolumn{18}{|c|}{ Precipitation and mean air-temperatures in eight sites* of Croatia } \\
\hline & \multicolumn{8}{|c|}{ The meteorological station } & \multicolumn{10}{|c|}{ The meteorological station } \\
\hline & OS & GR & SB & DA & $\mathrm{BJ}$ & SI & $\mathrm{ZG}$ & $\mathrm{VZ}$ & $\mathrm{x}$ & OS & GR & SB & DA & $\mathrm{BJ}$ & SI & ZG & $\mathrm{VZ}$ & $\mathrm{x}$ \\
\hline & \multicolumn{9}{|c|}{ The 2014 growing season } & \multicolumn{9}{|c|}{ Average 1961-1990 } \\
\hline & \multicolumn{18}{|c|}{ Precipitation $(\mathrm{mm})$} \\
\hline April & 81 & 88 & 119 & 123 & 106 & 124 & 70 & 105 & 102 & 54 & 53 & 58 & 77 & 54 & 73 & 64 & 70 & 63 \\
\hline May & 159 & 165 & 134 & 191 & 168 & 193 & 145 & 109 & 158 & 59 & 66 & 73 & 86 & 59 & 82 & 79 & 84 & 74 \\
\hline June & 91 & 46 & 78 & 54 & 80 & 74 & 147 & 118 & 86 & 88 & 81 & 86 & 99 & 88 & 91 & 100 & 98 & 91 \\
\hline July & 66 & 83 & 76 & 132 & 144 & 153 & 158 & 134 & 118 & 65 & 72 & 83 & 86 & 65 & 77 & 83 & 92 & 78 \\
\hline August & 54 & 94 & 132 & 125 & 127 & 169 & 115 & 153 & 121 & 59 & 66 & 73 & 91 & 58 & 85 & 95 & 98 & 78 \\
\hline September & 69 & 96 & 113 & 197 & 204 & 214 & 179 & 291 & 170 & 45 & 56 & 62 & 65 & 65 & 76 & 79 & 81 & 66 \\
\hline \multirow[t]{2}{*}{ Total } & 520 & 572 & 652 & 822 & 829 & 927 & 814 & 910 & 756 & 370 & 394 & 435 & 504 & 389 & 484 & 500 & 523 & 450 \\
\hline & \multicolumn{18}{|c|}{ Mean air-temperature $\left({ }^{\circ} \mathrm{C}\right)$} \\
\hline April & 13.2 & 13.3 & 12.8 & 12.3 & 13.0 & 13.1 & 13.3 & 12.7 & 13.0 & 11.3 & 11.5 & 10.9 & 11.0 & 11.3 & 11.1 & 10.6 & 10.3 & 11.0 \\
\hline May & 16.1 & 16.2 & 15.7 & 14.9 & 15.4 & 15.8 & 15.7 & 15.0 & 15.6 & 16.5 & 16.7 & 15.9 & 15.7 & 16.5 & 15.8 & 15.3 & 15.1 & 15.9 \\
\hline June & 20.4 & 20.7 & 20.0 & 19.6 & 20.1 & 20.3 & 20.2 & 19.3 & 20.1 & 19.5 & 19.6 & 19.0 & 18.9 & 19.5 & 19.1 & 18.5 & 18.3 & 19.1 \\
\hline July & 21.8 & 22.1 & 21.7 & 21.0 & 21.6 & 21.7 & 21.8 & 21.1 & 21.6 & 21.1 & 21.2 & 20.7 & 20.6 & 21.1 & 20.8 & 20.1 & 19.8 & 20.7 \\
\hline August & 20.8 & 20.9 & 20.6 & 19.7 & 20.2 & 20.2 & 20.2 & 19.2 & 20.2 & 20.3 & 20.7 & 19.8 & 19.7 & 20.3 & 19.8 & 19.3 & 18.9 & 19.9 \\
\hline September & 17.0 & 16.8 & 16.5 & 15.7 & 16.2 & 16.2 & 16.2 & 15.8 & 16.3 & 16.6 & 16.6 & 16.1 & 16.1 & 15.8 & 16.0 & 15.8 & 15.4 & 16.1 \\
\hline Mean & 18.2 & 18.3 & 17.9 & 17.2 & 17.8 & 17.9 & 17.9 & 17.2 & 17.8 & 17.6 & 17.7 & 17.1 & 17.0 & 17.4 & 17.1 & 16.6 & 16.3 & 17.1 \\
\hline
\end{tabular}

Source: MHS (2014), Note: * Osijek (OS), Gradiste (GR), Slavonski Brod (SB), Daruvar (DA), Bjelovar (BJ), Sisak (SI), Zagreb-Maksimir (ZG), Varazdin (VZ) 
In general, low yields of maize are in close connection with drought accompanied with high temperatures, particularly in two summer months July and August (Kovacevic et al., 2012; Stojic et al., 2012; Kovacevic et al., 2013; Videnovic et al., 2013; Majdancic et al., 2016). Weather conditions have similar role as in maize for their impact on yields of the other spring crops (Liovic et al., 2012; Vrataric and Sudaric, 2008; Kovacevic and Kaucic, 2014). Also, yields of winter crops are under considerable impacts of weather conditions, for example wheat (Marijanovic et al., 2010; Pepó and Kovacevic, 2011; Sostaric et al., 2014; Majdancic et al., 2016) and other winter crops (Iljkic et al., 2014).

Vucetic (2011) studied the impact of present climate on maize yield using DSSAT 4.0 with meteorological data from the Zagreb-Maksimir station covering the period 1949-2004. The location is representative of the continental climate in central Croatia. The linear trends of model outputs and the non-parametric MannKendall test indicate that the beginning of silking has advanced significantly by 1.4 days/decade since the mid-1990s and maturity by 4.5 days/decade. It also shows a decrease in biomass by $122 \mathrm{~kg} \mathrm{ha}^{-1}$ and in maize yield by $216 \mathrm{~kg} \mathrm{ha}^{-1}$ in 10 years.

Kovacevic et al. (2012) analyzed the data of the two-decade period between 1990-2012 of precipitation and temperature, with aspect of climatic in Serbia with emphasis on the Belgrade region. Annual air temperatures in the investigated period increased not only at the annual level, but also in the vegetative period of winter wheat and particularly maize. The temperature increase is particularly dangerous in the vegetative period of maize during June, July and August by almost $2{ }^{\circ} \mathrm{C}$. Precipitations at a monthly level of the vegetative period or a total per year do not provide such a picture. Besides the lack in July, precipitations are somewhat higher than the reference 30-year period 1971-2000.

Irrigation in critical stages under water deficit conditions is very useful management practice for elimination negative effects of drought on maize yield. For example, in stationary field experiment on eutric cambisol of Agricultural Institute Osijek, maize yield in less favorable growing seasons $(2000,2007$ and 2012) were increased compared to non-irrigated plot for $24.0 \%, 31.5 \%$ and $47.4 \%$, respectively (Table 4 ).

Also, by correspondingly soil management, for example liming and fertilization, is possible to alleviate negative effects of drought and high temperature on field crops yield (Kovacevic and Basic, 1997; Sostaric and Josipovic, 2006; Antunovic, 2008; Markovic et al., 2008, 2013; Komljenovic et al., 2010, 2015; Andric et al., 2012; Stojic et al., 2012; Kovacevic and Loncaric, 2014; Kovacevic et al., 2015).

Table 4.

Impacts of irrigation on maize yields

\begin{tabular}{|c|c|c|c|c|c|c|c|c|c|c|c|}
\hline \multirow{3}{*}{ Irrigation } & \multicolumn{11}{|c|}{ Response of maize to irrigation (the experimental field of Agricultural Institute Osijek) } \\
\hline & \multicolumn{11}{|c|}{ Grain yield of maize $\left(\mathrm{t} \mathrm{ha}^{-1}\right)^{* *}$} \\
\hline & 2000 & 2002 & 2004 & 2006 & 2007 & 2008 & 2009 & 2010 & 2011 & 2012 & Mean \\
\hline Control (non-irrigated) & 10.18 & 11.87 & 10.91 & 8.29 & 8.61 & 8.37 & 9.89 & 8.40 & 6.81 & 6.73 & 9.01 \\
\hline $80-100 \% \mathrm{FWC}^{*}$ & 12.62 & 12.44 & 11.97 & 10.32 & 11.32 & 9.65 & 12.20 & 8.56 & 9.23 & 9.92 & 10.82 \\
\hline $\mathrm{LSD}_{5 \%}$ & 0.65 & 0.13 & 0.49 & 0.27 & 0.44 & 0.30 & 0.22 & $\mathrm{~ns}$ & 0.35 & 0.32 & \\
\hline Yield increase $(\%)$ & 24.00 & 4.80 & 9.70 & 24.50 & 31.50 & 15.30 & 23.40 & 0 & 35.50 & 47.40 & \\
\hline
\end{tabular}

Source: Josipovic (2013), Note: * maintenance of soil moisture by irrigation in range $80-100 \%$ field water capacity (FWC), ** 2000-2004: average of 3 fertilization +4 replicates (12 individual results for each treatment), $* * 2005-2012$ : average of 3 fertilization +4 hybrids + 4 replicates (36 individual results for each treatment).

\section{CONCLUSIONS}

Maize, soybeans, sunflower and sugar beet are main field crops on arable land in Croatia. Weather conditions, particularly precipitation and temperature regimes, have considerable impact on yield of these four crops. With that regard, global warming and more frequency of the extremely weather conditions have often adverse influence on field crop yields as well the higher amplitude their variations among years. For example, in 15-year period (1999-2013) variation of annual yields were in ranges $\left(\mathrm{t} \mathrm{ha}^{-1}\right)$ from 4.1 to 8.0 (maize), from 1.4 to 3.0 (soybeans), from 1.6 to 3.2 (sunflower and from 23.0 to 57.7 (sugar beet). In general, the lower precipitation in combination with the higher temperatures are associated with the lower yields of maize, soybeans and sugar beet, while sunflower yields were low in very moist years. The growing season 2014 was mainly very favorable for spring crops because of adequate and good distributed precipitation and moderate temperatures. Under these favorable weather conditions, annual yields of maize $\left(8.1 \mathrm{tha}^{-1}\right)$, soybeans $\left(2.8 \mathrm{tha}^{-1}\right)$, sunflower $\left(2.9 \mathrm{tha}^{-1}\right)$ and sugar beet $63.6 \mathrm{t} \mathrm{ha}^{-1}$ ) were considerable higher than usual.

\section{REFERENCES}

Allen, L. H.-Pan, D.-Boote, K. J. Jr.-Pickering, N. B.-Jones, J. W. (2003): Carbon dioxide and temperature effects on evapotranspiration and water use efficiency of soybean. Agron. J. 95: 1071-1081.
Andric, L.-Rastija, M.-Teklic, T.-Kovacevic, V. (2012): Response of maize and soybeans to liming Turkish Journal of Agriculture and Forestry. 36: 415-420. 
Antunovic, M. (2008): Liming influences on maize and sugar beet yield and nutritional status. Cereal Res. Commun. 36. Suppl. $1839-1842$.

CBS (2005, 2009, 2014, 2015): Statistical Yearbook of the Republic of Croatia. Croatian Bureau of Statistics. Zagreb.

Chi-Chung, C.-Mc Carl, B. A.-Schimmelpfennig, D. (2004): Yield variability as influenced by climate: A statistical investigation. Climatic Change. 66: 239-261.

Iljkic, D.-Kovacevic, V.-Varga, I. (2014): Impact of climate change on wheat, barley and rapeseed yields in Croatia. [In: Maric, S.-Loncaric, Z. (eds.) Proceedings of the $49^{\text {th }}$ Croatian $\& 9^{\text {th }}$ International Symposium on Agriculture Dubrovnik, Croatia.] University J. J. Strossmayer in Osijek. Faculty of Agriculture. $357-361$.

Josipovic, M. (2013): Irrigation, protection of water and soil in sustainable agriculture of the eastern Croatia. Agricultural Institute Osijek (Internal arhive of Institute).

Komljenovic, I.-Markovic, M.-Djurasinovic, G.-Kovacevic, V. (2015): Response of maize to liming and phosphorus fertilization with emphasis on weather properties effects. Columella - Journal of Agricultural and Environmental Sciences. 2. 1: 29-35.

Komljenovic, I.-Markovic, M.-Kondic, D. -Kovacevic, V. (2010): Response of maize to phosphorus fertilization on hydromorphic soil of Bosnian Posavina area. Poljoprivreda/Agriculture. 16: 9-13.

Komljenovic, I.-Misic, M.-Markovic, M. -Pesevic, D.--Markovic, M. (2014): The climate data analysis of Banja Luka area as the basis of agricultural adaptation to climate change planning Conference proceedings of People, Buildings and Environment 2014. Kroměříž. Czech Republic. 592-603.

Kovacevic, D.-Oljaca, S.-Dolijanovic, Z.-Milic, V. (2012): Climate changes: ecological and agronomic options for mitigating the consequences of drought in Serbia. Book of Proceedings - Third International Scientific Symposium "Agrosym Jahorina 2012”. November 15-17, 2012. Jahorina. 17-35.

Kovacevic, V.-Basic, F. (1997): The soil potassium resources and the efficiency of potassium fertilizers in Croatia. Country Report. No 10

Kovacevic, V.-Josipovic, M. -Grgic, D. (1994): Survey of results of maize production in Slavonia and Barannya region (1960 1989). Poljoprivredne aktualnosti. 3-4: 495-503.

Kovacevic, V.-Kaucic, D. (2014): Climatic changes impacts on maize, sugar beet, soybeans and sunflower yields in Croatia. [In: Maric, S.-Loncaric, Z. (eds.) Proceedings of the $49^{\text {th }}$ Croatian \& $9^{\text {th }}$ International Symposium on Agriculture Dubrovnik, Croatia.] University J. J. Strossmayer in Osijek. Faculty of Agriculture. 382-386.

Kovacevic, V.-Kovacevic, D.-Pepó, P.-Markovic, M. (2013): Climate change in Croatia, Serbia, Hungary and Bosnia and Herzegovina: comparison the 20210 and 2012 maize growing seasons. Poljoprivreda/Agriculture. 19: 16-22.

Kovacevic, V.-Loncaric, Z. (2014): Using of carbocalk for improvement of soil fertility. Technologica Acta. 7. 1: 1-8.

Kovacevic, V.-Rastija, M. (2014): The Cereals (university textbook). University. J. J. Strossmayer in Osijek. Faculty of Agriculture. Croatia.

Kovacevic, V.-Rastija, M.-Brkic, I.-Sostaric, J. (2014): Survey of maize growing in Croatia. [In: Szilvássy Z. (ed.) A fenntartható növénytermesztés fejlesztési lehetőségei.] 274-279.

Kovacevic, V.-Rastija, M.-Sudar, R.-Iljkic, D.-Varga, I. (2015): Response of maize and wheat to fertdolomite application. Columella - Journal of Agricultural and Environmental Sciences. 2. 1: 19-25.
Li, X.-Takahashi, T.-Nobuhiro Suzuki, N.-Harry, M.-Kaiser, H. M. (2011): The impact of climate change on maize yields in the United States and China. Agricultural Systems. 104: 348-353.

Liovic, I.-Mijic, A.-Krizmanic, M.-Pepó, P.-Kovacevic, V.Markulj, A.-Duvnjak, T.-Krizmanic, G. (2012): Influence of sunflower cytoplasmic male sterile and restorer line on grain yield stability among different environmental conditions. Acta Agronomica Hungarica. 60. 3: 247-255.

Lobell, D-Field, C. (2007): Global scale climate-crop yield relationships and the impacts of recent warming. Public Health Resources -Paper 1.

Magas, D. (2013): Geography of Croatia. Biblioteka Geographia Croatica. Book 46. The first edition. University of Zadar Department of Geography and Meridijani. Editing House Samobor. Croatia.

Majdancic, M.-Basic, M.-Salkic, B.-Kovacevic, V.-Rastija, M.Jovic, J. (2016): Weather conditions and yield of wheat in Bosnia and Herzegovina with emphasis on climatic change and Tuzla Canton. Journal of Agriculture and Ecology Research International. 7. 2: 1-9.

Majdancic, M.-Basic, M.-Salkic, B.-Kovacevic, V.-Jovic, J. (2016): Weather conditions and yields of maize in Federation of Bosnia and Herzegovina with emphasis on Tuzla Canton. Works of the Faculty of Agriculture and Food Sciences. University of Sarajevo. LXI. 66. 1: 303-307.

Marijanovic, M.-Markulj, A.-Tkalec, M.-Jozic, A.-Kovacevic, V. (2010): Impact of precipitation and temperature on wheat (Triticum aestivum L.) yields in eastern Croatia. Acta Agriculturae Serbica. 15. 29: 117-123.

Markovic, M.-Josipovic, M.-Sostaric, J.-Rastija, D. (2013): Irrigation and liming as factors of maize yield increases in eastern Croatia. Trakya University Journal of Natural Sciences. 14. 2: 93-95.

Markovic, M.-Komljenovic, I.-Todorovic, J.-Biberdzic, M.Delalic, Z. (2008): Response of maize to liming in northern Bosnia. Cereal Res. Commun. 36. Suppl. 2079-2082.

MHS (1999-2013): The Climatological Reports for Osijek Weather Bureau. Meteorological and Hydrological Service Zagreb.

MHS (2014): The Climatological Reports for Osijek, Gradiste, Slavonski Brod, Daruvar, Bjelovar, Sisak, Zagreb-Maksimir and Varazdin Weather Bureaues. Meteorological and Hydrological Service Zagreb.

Oseni, T. O.-Masarirambi, M. T. (2011): Effect of Climate Change on Maize (Zea mays) Production and Food Security in Swaziland. American-Eurasian J. Agric. \& Environ. Sci. 11. 3: 385-391.

Pepó, P.-Kovacevic, V. (2011): Regional analysis of winter wheat yields under different ecological conditions in Hungary and Croatia. Acta Agronomica Hungarica. 59: 23-33.

Rastija, M.-Iljkic, D. -Kovacevic, V.-Brkic, I. (2012): Weather impacts on maize productivity in Croatia with emphasis on 2011 growing season. Növénytermelés. 61: Suppl. 329-332.

Sostaric, J.-Begic, S.-Salkic, B.-Kovacevic, V.-Markovic, M. (2014): Variation of winter wheat yields in Croatia and Bosnia and Herzegovina among years with aspect of climatic changes. Turkish Journal of Agricultural and Natural Sciences. Special Issue. 1: 1364-1368.

Sostaric, J.-Josipovic, M. (2006): Weather and soil influences on maize yield in the eastern Croatia. Universitatea se Stiente Agricole si Medicina Veterinara Iasi, Lucrari Stiintifice. Seria Agronomie. 49: 218-222.

Stojic, B.-Kovacevic, V.-Seput, M.-Kaucic, D.-Mikoc, V. (2012): Maize yields variation among years as function of weather regimes and fertilization. Növénytermelés. 61: Suppl. 85-88. 
Thomson, A. M. R. A.-Brown, N. J.- Roseberg, R.-Lazuralde, C.Benson, V. (2005): Climate change impacts for the conterminous USA: an integrated assessment Part 3. Dry land production of grain and forage Crops. Climate Change. 69: 43-65.

Tim, H. (2000): The impact of climatic variability over the period 1961-1990 on the soil water balance of upland soils in the North East Arid Zone of Nigeria. U.K. Met Office 2000. Climate Change - An Update of Recent Research from the Hadley Centre.

Videnovic, Z.-Dumanovic, Z.-Simic, M.-Srdic, J.-Babic, M.Dragicevic, V. (2013): Genetic potential and maize production in Serbia. Genetika. 45. 3: 667-677.
Vrataric, M.-Sudaric, A. (2008): Soybean. Agricultural Institute Osijek. Croatia.

Vucetic, V. (2006): Modelling of the maize production and the impact of climate change on maize yields in Croatia (final report) Meteorological and hydrometeorological service of Republic of Croatia. Zagreb.

Vucetic, V. (2011): Modelling of maize production in Croatia: present and future climate. Journal of Agricultural Science. 149: $145-157$. 